\title{
Reduction of Bacterial Spot Disease Severity on Tomato and Pepper Plants with Foliar Applications of Ammonium Lignosulfonate and Potassium Phosphate
}

\author{
Pervaiz A. Abbasi, Nader Soltani, Diane A. Cuppels, and George Lazarovits, Southern Crop Protection \& Food \\ Research Centre, Agriculture and Agri-Food Canada, London, ON N5V 4T3, Canada
}

\begin{abstract}
Abbasi, P. A., Soltani, N., Cuppels, D. A., and Lazarovits, G. 2002. Reduction of bacterial spot disease severity on tomato and pepper plants with foliar applications of ammonium lignosulfonate and potassium phosphate. Plant Dis. 86:1232-1236.

Bacterial spot is a serious and persistent disease problem of tomato and bell pepper in both the United States and Canada. Current disease management practices, based primarily on fixed copper bactericides, do not give consistent, effective protection. Foliar applications of ammonium lignosulfonate (ALS), derived from the wood pulping process, and the fertilizer potassium phosphate (KP) were tested for their ability to control this disease under both greenhouse and field conditions. Acibenzolar- $S$-methyl was included as a control. Greenhouse-grown tomato transplants treated with acibenzolar-S-methyl, 2 or $4 \%$ (vol/vol) ALS, $25 \mathrm{mM} \mathrm{KP}$, or $2 \%$ ALS plus $10 \mathrm{mM} \mathrm{KP}$ and then inoculated with Xanthomonas campestris pv. vesicatoria had significantly less disease than the unprotected controls. Weekly foliar applications of acibenzolar- $S$ methyl, ALS, or KP significantly reduced disease severity on the foliage of inoculated fieldgrown tomato and pepper plants; although less disease appeared on the fruit of these plants, the effect was not always statistically significant except for the acibenzolar- $S$-methyl treatment. Acibenzolar- $S$-methyl increased the yield of marketable tomato fruit in 2 of 3 years of the study and that of pepper fruit in 1 of 2 years. There was a marked increase in the yield of marketable fruit on all ALS-treated pepper plants in 2001. None of the treatments significantly increased total tomato or pepper yield. ALS and KP had no observable phytotoxic effect on tomato or pepper foliage. Our results indicate that future integrated disease management programs for bacterial spot may be enhanced by including foliar sprays of these two products.
\end{abstract}

Additional keywords: Actigard, Capsicum anпиum, foliar fertilizer, induced resistance, Lycopersicon esculentum, potassium phosphate, Xanthomonas axonopodis pv. vesicatoria, $X$. vesicatoria

Bacterial spot is an economically important disease of processing and fresh market tomato (Lycopersicon esculentum Mill.) and bell pepper (Capsicum annum L.) in Ontario and other tomato- and peppergrowing areas. The pathogen, Xanthomonas campestris pv. vesicatoria (X. vesicatoria and $X$. axonopodis pv. vesicatoria; 39), infects all the aboveground plant parts, causing necrotic lesions on leaves, stems, and fruit. Disease development is favored by high moisture and temperature, conditions prevalent during the growing season for these vegetables in Ontario. This disease can cause serious economic losses to tomato and pepper growers by reducing

Corresponding author: G. Lazarovits

E-mail: lazarovitsg@em.agr.ca

This research was funded by a grant from Tembec Inc., and the AAFC Matching Investment Initiative.

Accepted for publication 11 June 2002.

Publication no. D-2002-0823-01R

This article is in the public domain and not copyrightable. It may be freely reprinted with customary crediting of the source. The American Phytopathological Society, 2002. yield and fruit quality. Growers rely heavily on fixed copper sprays to manage foliar disease and reduce losses caused by bacterial spot and bacterial speck $(10,15,17)$. Unfortunately, these sprays often are not very effective and their extensive use has led to the development of copper-resistant strains $(2,12,28,31)$. Currently, there are no commercial cultivars resistant to all races of the bacterial spot pathogen. In the absence of effective disease management practices, this disease presents a continued threat to tomato and pepper production. Therefore, new approaches for the management of this disease are needed.

Acibenzolar-S-methyl, a benzothiadiazole-derivative and a plant activator, is a synthetic compound that has been shown to mediate the induction of systemic acquired resistance (SAR) in several plant species against a number of pathogens $(9,13,29,30,38)$. It has been registered in Europe as Bion 50 WP (Syngenta Ltd., Basel, Switzerland) and in the United States as Actigard (Syngenta Crop Protection, Greensboro NC) but it is not yet available to growers in Canada. Its efficacy against bacterial spot and bacterial speck of tomato and pepper under greenhouse and field conditions has been shown previously $(1,11,18,21)$.

Ammonium lignosulfonate (ALS) is derived from the spent sulfite liquors produced during the wood pulping process. Most of this high-lignin-content product is disposed of by incineration. ALS has a high organic matter content and a potential to be used as an organic fertilizer. When used as a soil amendment, ALS improves the physical and physicochemical properties of saline and eroded soils and reduces evaporative soil water loss $(5,6)$. In addition, lignosulfonate also is known to serve as a carrier of micro and macro nutrients and increase their availability to and uptake by plants $(4,8,20,24,32,34,42-44)$. Recently, our laboratory demonstrated the potential use of ALS as a soil amendment to enhance plant growth and manage soilborne plant diseases such as Verticillium wilt and potato scab $(35,36)$. ALS is soluble in water and easily can be sprayed onto foliage. The effects of foliar applications of ALS on foliar diseases caused by bacterial pathogens and on yield have not yet been investigated.

Recently, several studies have shown the effectiveness of foliar application of potassium phosphate fertilizers in controlling powdery mildew on many plant species and in controlling northern leaf blight and rust on corn by inducing local and systemic resistance (25-27). Phosphate salts induce resistance in several plants against several pathogens $(3,14,25-27,41)$. For instance, phosphates have been shown to induce systemic resistance in cucumber plants and in broad beans against the anthracnose pathogen Colletotrichum lagenarium (14) and the rust pathogen Uromyces viciaefabae (41), respectively. The effects of foliar applications of potassium phosphate (KP) on bacterial pathogens have not yet been investigated.

The objectives of this study were to determine the effects of foliar applications of ALS and KP on the development of bacterial spot on foliage and fruit and on the yield of tomato and pepper fruit.

\section{MATERIALS AND METHODS}

Bacterial strains. The bacterial strains used in this study, $X$. campestris pv. vesicatoria strain DC 93-1 (group B) and $X$. campestris pv. vesicatoria strain DC 96-1 (group A), were isolated from an Ontario tomato and pepper field, respectively. They were stored in $20 \%$ glycerol at $-80^{\circ} \mathrm{C}$. For 
inoculum production, the strains were streaked out on nutrient broth yeast extract (NBY) agar (40).

Chemicals. The ALS used in this study was supplied by Tembec Inc. (Témiscaming, Québec, Canada) as 50\% solids in solution. It was diluted by $20 \%$ using water to have a stock solution that was thin enough to prepare final concentrations. All the concentrations used in this study represent percent ( $\mathrm{vol} / \mathrm{vol})$ of the original ALS (50\% solids). Thus, the 2 and $4 \%$ ALS solutions reported here were 1 and $2 \%$ solids, respectively. The $\mathrm{pH}$ of aqueous ALS is 3.9. Acibenzolar- $S$-methyl (Actigard; 50 WP) was supplied by Syngenta Crop Protection Inc. (Guelph, Ontario, Canada). Potassium phosphate (dipotassium hydrogen phosphate, $\mathrm{K}_{2} \mathrm{HPO}_{4}$ ) was purchased from Fisher Scientific (Fair Lawn, NJ).

Greenhouse experiments. Tomato transplants of the processing tomato cultivar Heinz 9478 were grown in a commercial peat mix (Pro-Mix 'BX', Premier Horticulture Inc., Rivière-du-Loup, Québec, Canada) in $10-\mathrm{cm}$ pots (one plant per pot). Each pot received 6 to 8 granules of controlled release fertilizer Nutricote (14-1414; Plant Products Co. Ltd., Brampton, Ontario, Canada) during transplanting. Treatments were arranged in a completely randomized design with five replicates per treatment. Four-week-old tomato transplants were sprayed with aqueous solutions of ALS ( 2 or $4 \% \mathrm{vol} / \mathrm{vol}), \mathrm{KP}(25 \mathrm{mM})$, acibenzolar- $S$-methyl, (35 $\mathrm{mg}$ a.i./liter), or a combination of ALS (2\%) and KP (10 $\mathrm{mM})$. Control plants were sprayed with water. Treatments were applied twice at 1week intervals, one application before and one after inoculation. For inoculation purposes, $X$. campestris pv. vesicatoria strain DC 93-1 was grown overnight in NBY broth, collected by centrifugation $(10,000$ $\mathrm{rpm}$ for $15 \mathrm{~min}$ ), and resuspended in sterile tap water. The bacterial concentration was adjusted to $10^{8} \mathrm{CFU} / \mathrm{ml}$ and plants were spray inoculated 3 days after the first treatment application. Inoculated plants were kept on a greenhouse bench and rated for foliar bacterial spot disease severity 2 weeks after inoculation using the following scale: $1=$ symptomless, $2=$ a few necrotic spots on a few leaflets, $3=$ a few necrotic spots on many leaflets, $4=$ many spots with coalescence on few leaflets, $5=$ many spots with coalescence on many leaflets, 6 $=$ severe disease and leaf defoliation, and 7 $=$ plant dead. Greenhouse experiments were repeated twice.

Field experiments. Field studies were conducted in London, Ontario during the 1999, 2000, and 2001 seasons. Tomato plots were established all 3 years, whereas pepper was included only in the 2000 and 2001 trials. Tomato and pepper plots were adjacent to each other in the same field. They were established in a randomized block design with four replicates per treatment. Tomato (cv. H 9478) and pepper (cv.
Merlin) transplants grown in a Pro-Mix ' $\mathrm{BX}$ ' peat mix in plug trays were supplied by H. J. Heinz (Leamington, Ontario, Canada). Standard cultivation practices were carried out. Seedlings were planted $0.45 \mathrm{~m}$ apart in single rows on $1.2-\mathrm{m}$ centers with a planter. Plants were fertilized with the plant starter Plant Prod (10-52-10; Plant Products Co. Ltd.) during planting; each plant received approximately 150 to 180 $\mathrm{ml}$ of $0.5 \%$ starter fertilizer. Aqueous solutions of ALS ( 2 or $4 \% \mathrm{vol} / \mathrm{vol}$ ), KP (25 $\mathrm{mM}$ ), acibenzolar- $S$-methyl, (35 g a.i./ha), or a combination of ALS (2\%) and KP (10 or $25 \mathrm{mM}$ ) were applied weekly as spray treatments throughout the growing season starting 2 weeks after transplanting. A total of 12 applications were made in 1999 and 10 in 2000 and 2001. Control plots were sprayed with water. Plants in the border rows were inoculated and bacterial spot was allowed to spread naturally to the treated plants. Inoculum was produced as described above. The tomato border rows were inoculated with $X$. campestris pv. vesicatoria strain DC 93-1 while the pepper border rows were inoculated with $X$. campestris pv. vesicatoria strain DC 96-1. During 1999, bacterial speck (Pseudomonas syringae pv. tomato) spread from nearby tomato plants into the plots. Other foliar and fruit diseases occurring naturally on these plants included early blight ( $\mathrm{Al}$ ternaria solani (Ellis \& G. Martin) L. R. Jones \& Grout), Septoria leaf spot (Septoria lycopersici Speg.), and anthracnose (Colletotrichum spp.). In the field plots, plants were rated for foliar bacterial disease severity four times (16 August, 23 August, 1 September, and 7 September 1999) or five times (20 July, 31 July, 11 August, 21 August, and 29 August 2000; and 27 July, 3 August, 10 August, $17 \mathrm{Au}-$ gust, and 24 August 2001). Plants were rated for foliar bacterial disease severity (1999, spot and speck; 2000 and 2001, spot only) according to a modified Horsfall and Barrett disease rating scale, where $1=$ no disease and $12=100 \%$ disease (16). The disease severity data for each treatment were converted to area under the disease progress curve (AUDPC) using the midpoints of each rating (percent disease; 7,33). All fruit from eight plants in 1999, five plants in 2000, and eight plants in 2001, in the middle of each replicate plot (four replicate plots/treatment), was harvested when approximately $80 \%$ of the tomato fruit was ripe. Fruit were analyzed for the incidence of bacterial diseases (1999, spot and speck; 2000 and 2001, spot only) and anthracnose. A fruit with one or more bacterial spot-like lesions was considered diseased. Incidence of bacterial diseases was expressed as a percentage of total harvested fruit on a weight basis. Tomato and pepper fruit free of any disease symptoms were considered marketable. Total yields also were determined. Individual peppers also were analysed for bacte- rial spot severity by counting the number of lesions on each fruit.

Statistical analyses. Greenhouse data were analyzed using Minitab statistical software (version 13; Minitab Inc., State College, PA). Analysis of variance was performed and means were separated according to Fisher's protected least significant difference test. Field data were analyzed using SAS statistical software (version 8.0; SAS Institute Inc., Cary, NC). Data were tested for normality and, if required, transformed to normalize before analysis (37). Actual means were reported in the tables for clarity. Analysis of variance was performed by using the general linear models procedure of SAS and means were separated with least squares estimates of marginal means (LSMEANS statement).

\section{RESULTS}

Effect of ALS and KP on bacterial spot severity on greenhouse-grown tomato plants. ALS, KP, and acibenzolar- $S$ methyl consistently reduced bacterial spot severity on greenhouse-grown tomato plants (Table 1). A mixture of ALS (2\%) and $\mathrm{KP}(10 \mathrm{mM})$ also consistently and effectively reduced disease severity. Tomato transplants treated with ALS (2 or $4 \%)$ or KP (10 or $25 \mathrm{mM})$ showed no obvious phytotoxic effects, whereas acibenzolar-S-methyl (35 $\mathrm{mg}$ a.i./liter) was phytotoxic, causing stunting, chlorosis, epinasty, narrowing of leaf blades, and defoliation.

Effect of ALS and KP on bacterial spot severity on the foliage and incidence on the fruit of field-grown tomato plants. In 1999, weekly foliar sprays with ALS (2 or $4 \%$ ), KP, and acibenzolar-Smethyl significantly reduced bacterial dis-

Table 1. Effect of foliar sprays of acibenzolar$S$-methyl (Actigard), ammonium lignosulfonate (ALS), and potassium phosphate (KP) on bacterial spot disease severity on greenhousegrown tomato plants

\begin{tabular}{lc}
\hline $\begin{array}{l}\text { Spray } \\
\text { treatments }^{\mathbf{y}}\end{array}$ & $\begin{array}{c}\text { Mean bacterial spot } \\
\text { severity }^{\mathbf{z}}\end{array}$ \\
\hline Control & $4.9 \mathrm{a}$ \\
Actigard & $1.9 \mathrm{c}$ \\
ALS $(2 \%)$ & $3.0 \mathrm{~b}$ \\
ALS (4\%) & $2.9 \mathrm{~b}$ \\
KP & $2.7 \mathrm{~b}$ \\
ALS + KP & $2.6 \mathrm{~b}$ \\
\hline
\end{tabular}

${ }^{y}$ Four-week-old tomato transplants (cv. H9478) were sprayed twice at 1-week intervals with Actigard (35 mg a.i./liter), ALS (2 and $4 \% \mathrm{vol} / \mathrm{vol}), \mathrm{KP}(25 \mathrm{mM})$, or a mixture of $\operatorname{ALS}(2 \%)$ and $\mathrm{KP}(10 \mathrm{mM})$

${ }^{\mathrm{z}}$ Plants were inoculated with Xanthomonas campestris pv. vesicatoria 3 days after the first spray treatment and rated for bacterial spot disease severity 2 weeks later according to a 1-to-7 scale, where $1=$ symptomless and $7=$ dead plant. Disease severity data are an average of three experiments $(n=15)$. Means followed by different letters within each column are significantly different from each other according to Fisher's protected least significant difference test $(P \leq 0.05)$. 
ease severity on tomato foliage compared with the water control (Table 2). Although the plots had been inoculated with the bacterial spot pathogen, bacterial speck, coming from a nearby speck trial, also was present. Some Alternaria blight and Septoria leaf spot also was seen on the foliage. In 2000, tomato plots were flooded by heavy rains during June and July. Despite a large variation among the experimental replicates, acibenzolar-S-methyl, 2\% ALS, 4\% ALS, and KP reduced bacterial spot disease severity on tomato foliage. The 2001 growing season was comparatively dry during June and July and disease pressure was low on tomato plots, despite plots being irrigated weekly and inoculated twice. The second inoculation was made directly onto the treated plants, not the border rows. The severity of bacterial spot on tomato foliage was reduced by acibenzolar-S-methyl, $4 \%$ ALS, KP, and the ALS-KP mixture.

Although a few bacterial speck lesions were found on tomato fruit in 1999, the predominant disease was bacterial spot during the 3-year field study. In 1999, 4\% $\mathrm{ALS}, \mathrm{KP}$, and acibenzolar-S-methyl significantly reduced the incidence of bacterial disease on the fruit by 25,41 , and $62 \%$, respectively (Table 2 ). In 2000 , bacterial spot pressure was very high due to heavy rains and flooding and only the acibenzolar- $S$-methyl treatment significantly reduced the disease on fruit. However, the relative effectiveness of the other treatments resembled that seen in 1999. There was a 25,27 , and $48 \%$ reduction in disease incidence on fruit with $4 \%$ ALS, KP, and acibenzolar- $S$-methyl treatments, respectively (Table 2). In 2001, bacterial spot pressure on tomato was low during early flowering and most of the fruit escaped infection. In control plots, only $13.6 \%$ of the total fruit was infected. Foliar sprays of acibenzolar- $S$-methyl and a combination of ALS and KP significantly reduced the incidence on fruit by 54 and $53 \%$, respectively (Table 2).

Table 2. Effect of weekly foliar sprays of acibenzolar-S-methyl (Actigard), ammonium lignosulfonate (ALS), or potassium phosphate (KP) on the bacterial disease severity on foliage (AUDPC) and incidence on fruit of field-grown tomatow

\begin{tabular}{|c|c|c|c|c|c|c|}
\hline \multirow[b]{2}{*}{ Spray treatments } & \multicolumn{3}{|c|}{ Foliar AUDPC ${ }^{x}$} & \multicolumn{3}{|c|}{ Diseased fruit $(\%)^{\mathrm{y}}$} \\
\hline & 1999 & 2000 & 2001 & 1999 & 2000 & 2001 \\
\hline Control & $529 \mathrm{a}$ & $441 \mathrm{a}$ & $219 a$ & $32.0 \mathrm{a}$ & $50.3 \mathrm{a}$ & $13.6 \mathrm{a}$ \\
\hline Actigard & $66 \mathrm{c}$ & $113 \mathrm{c}$ & $34 \mathrm{c}$ & $12.3 \mathrm{c}$ & $26.0 \mathrm{~b}$ & $6.3 \mathrm{~b}$ \\
\hline $\operatorname{ALS}(2 \%)$ & $110 \mathrm{~b}$ & $241 \mathrm{~b}$ & $140 \mathrm{ab}$ & $26.7 \mathrm{ab}$ & $44.2 \mathrm{a}$ & $9.4 \mathrm{ab}$ \\
\hline $\operatorname{ALS}(4 \%)$ & $118 \mathrm{~b}$ & $238 \mathrm{~b}$ & $96 \mathrm{~b}$ & $24.0 \mathrm{~b}$ & $37.8 \mathrm{a}$ & $8.7 \mathrm{ab}$ \\
\hline $\mathrm{KP}$ & $188 \mathrm{~b}$ & $268 \mathrm{~b}$ & $99 \mathrm{~b}$ & $18.9 \mathrm{~b}$ & $37.0 \mathrm{a}$ & $8.9 \mathrm{ab}$ \\
\hline $\mathrm{ALS}+\mathrm{KP}^{\mathrm{z}}$ & $\ldots$ & $274 \mathrm{bc}$ & $113 \mathrm{~b}$ & $\ldots$ & $44.3 \mathrm{a}$ & $6.4 \mathrm{~b}$ \\
\hline
\end{tabular}

${ }^{\mathrm{w}}$ AUDPC $=$ area under the disease progress curve. Means followed by different letters within each year are significantly different $(P \leq 0.05$, least squares means option of the general linear models procedure of SAS).

${ }^{\mathrm{x}}$ Foliar disease severity was assessed four to five times during the season using a Horsfall-Barratt rating scale (16). The AUDPC was calculated using midpoints (percent foliar disease) of each rating. In all 3 years, bacterial spot was the predominant disease; however, in 1999, bacterial speck also was present.

${ }^{y}$ Incidence of bacterial spot and speck (1999) and bacterial spot (2000 and 2001) on fruit at harvest expressed as percentage of harvested fruit with bacterial spot.

z A mixture of ALS (2\%) and KP (10 mM in 2000 and $25 \mathrm{mM}$ in 2001).

Table 3. Effect of weekly foliar sprays of acibenzolar-S-methyl (Actigard), ammonium lignosulfonate (ALS), or potassium phosphate (KP) on the bacterial disease severity on foliage (AUDPC) and incidence on fruit of field-grown pepper ${ }^{\mathrm{V}}$

\begin{tabular}{|c|c|c|c|c|c|c|}
\hline \multirow[b]{2}{*}{ Spray treatments } & \multicolumn{2}{|c|}{ Foliar AUDPC $^{w}$} & \multicolumn{2}{|c|}{ Diseased fruit $(\%)^{\mathrm{x}}$} & \multicolumn{2}{|c|}{ Spots/fruity } \\
\hline & 2000 & 2001 & 2000 & 2001 & 2000 & 2001 \\
\hline Control & 339 a & $191 \mathrm{a}$ & $98.1 \mathrm{a}$ & $60.7 \mathrm{a}$ & $8.5 \mathrm{a}$ & $5.4 \mathrm{a}$ \\
\hline Actigard & $46 \mathrm{c}$ & $39 \mathrm{c}$ & $35.2 \mathrm{c}$ & $20.9 \mathrm{c}$ & $0.7 \mathrm{c}$ & $0.7 \mathrm{~b}$ \\
\hline $\operatorname{ALS}(2 \%)$ & $171 \mathrm{~b}$ & $96 \mathrm{~b}$ & $73.4 \mathrm{~b}$ & $43.3 \mathrm{ab}$ & $3.2 \mathrm{bc}$ & $2.6 \mathrm{ab}$ \\
\hline $\operatorname{ALS}(4 \%)$ & $189 \mathrm{~b}$ & $63 \mathrm{bc}$ & $89.9 \mathrm{ab}$ & $47.4 \mathrm{ab}$ & $4.5 \mathrm{~b}$ & $2.7 \mathrm{ab}$ \\
\hline $\mathrm{KP}$ & $161 \mathrm{~b}$ & $146 \mathrm{ab}$ & $76.8 \mathrm{ab}$ & $48.1 \mathrm{ab}$ & $5.9 \mathrm{ab}$ & $4.6 \mathrm{a}$ \\
\hline $\mathrm{ALS}+\mathrm{KP}^{\mathrm{z}}$ & $211 a b$ & $101 \mathrm{~b}$ & $76.9 \mathrm{ab}$ & $40.5 \mathrm{~b}$ & $5.7 \mathrm{ab}$ & $1.9 \mathrm{~b}$ \\
\hline
\end{tabular}

${ }^{\mathrm{V}}$ AUDPC $=$ area under the disease progress curve. Means followed by different letters within each year are significantly different $(P \leq 0.05$, least squares means option of the general linear models procedure of SAS).

w Foliar disease severity was assessed four to five times during the season using a Horsfall-Barratt rating scale (16). The AUDPC was calculated using midpoints (percent foliar disease) of each rating. In all 3 years, bacterial spot was the predominant disease; however, in 1999, bacterial speck also was present.

${ }^{\mathrm{x}}$ Incidence of bacterial spot on fruit at harvest expressed as percentage of harvested fruit with bacterial spot.

${ }^{\mathrm{y}}$ Individual pepper fruit were analyzed for the severity of bacterial spot.

${ }^{\mathrm{z}}$ A mixture of ALS (2\%) and KP (10 mM in 2000 and $25 \mathrm{mM}$ in 2001).

Effect of ALS and KP on bacterial spot severity on the foliage and incidence on the fruit of field-grown pepper plants. Bacterial spot was the main disease on pepper in both seasons. In 2000, heavy rains and flooding during June and July resulted in high disease pressure in the plots. Despite a large variation among the experimental plots, acibenzolar- $S$-methyl, $2 \%$ ALS, 4\% ALS, and KP reduced bacterial spot disease severity on pepper foliage (Table 3). In 2001, bacterial spot pressure was low on pepper early in the season, but the disease spread quickly as the season progressed. The severity of bacterial spot on pepper foliage was reduced by all treatments except KP (Table 3 ).

In $2000,98 \%$ of the fruit from untreated pepper plants had disease symptoms. Only the acibenzolar-S-methyl and 2\% ALS significantly reduced bacterial spot incidence (Table 3). In 2001, $60.7 \%$ of pepper fruit in the control plot developed bacterial spot symptoms. Acibenzolar- $S$-methyl and a mixture of ALS and KP treatments significantly reduced the incidence of bacterial spot on peppers by 66 and 33\%, respectively (Table 3 ).

Each harvested pepper fruit was analyzed for disease severity (Table 3). The number of lesions/fruit was significantly reduced by acibenzolar- $S$-methyl in both years, and by ALS ( 2 or $4 \%$ ) in 2000. The severity of the disease was not affected by foliar sprays of KP; however, the combination of ALS and KP significantly reduced the disease on pepper in 2001.

Effect of ALS and KP on the yield of field-grown tomato plants. In 1999 and 2000, all treatments increased the number of healthy tomato fruit compared with the water control, but the increase was significant only with acibenzolar- $S$-methyl (Table 4). In 2001, disease-free tomato yields were not affected by any spray treatment. The 2000 season was comparatively wet and tomato yield was low compared with 1999 and 2001. None of the sprays significantly increased total tomato yield during the 3-year study (Table 4).

There were no obvious phytotoxic effects of the ALS and KP treatments on the foliage of the field-grown tomato plants. The phytotoxic effects observed on acibenzolar-S-methyl-treated greenhouse-grown tomato plants (as described above) were not seen on the field-grown tomato plants.

Effect of ALS and KP on the yield of field-grown pepper plants. The number of pepper fruit per plant in 2000 was low compared with the number in 2001. The only treatment that adversely affected the number of pepper fruit/plant was acibenzolar-S-methyl (Table 5). In 2000, bacterial spot disease pressure was very high in the pepper plots, resulting in low yields. There was substantial variation among the replicate plots and no treatment had a significant impact on the yield of healthy pepper fruit (Table 5). ALS and KP also did not 
significantly affect total yield; acibenzolar$S$-methyl actually reduced total yield. In the following year, all treatments, except $\mathrm{KP}$, significantly increased the number of healthy pepper fruit harvested; however, the total yield was not affected (Table 5).

There were no obvious phytotoxic effects of the ALS and KP treatments on the foliage of the field-grown pepper plants.

\section{DISCUSSION}

Disease management options currently available to growers do not provide adequate control of bacterial spot of tomato and pepper and there is a need for new disease management strategies. In this study, we investigated the effect of foliar sprays of ALS and KP on bacterial spot development on tomato and pepper. In the greenhouse, tomato plants treated with ALS, KP, or a combination of ALS and KP consistently had less bacterial spot. Treated plants looked healthy and showed no symptoms of phytotoxicity. Tomato field trials were conducted in 1999, 2000, and 2001, with bell pepper trials being included in 2000 and 2001. Bacterial spot severity on tomato foliage was reduced by ALS and $\mathrm{KP}$ treatments throughout the study despite major differences in the weather conditions. Although not always statistically significant, the ALS and KP treatments resulted in less disease on the fruit. There was no effect on total yields, but the ALS sprays did increase the number of healthy pepper fruit harvested in 2001.

Manipulation of host nutrition has been shown to effectively manage plant diseases caused by soilborne and foliar pathogens of a number of crops, including tomato and pepper $(19,22,23)$. For instance, in an earlier greenhouse study, Nayudu and Walker (23) reported a decrease in bacterial spot lesions on tomato plants treated with high levels of nitrogen, potassium, and phosphorus fertilization. Similarly, increased potassium has been shown to reduce the bacterial spot intensity on greenhousegrown chili transplants (22). A field study demonstrated that tomato plants receiving higher rates of nitrogen and potassium fertilization through drip irrigation had lower epiphytic populations of $X$. campestris pv. vesicatoria, resulting in reduced bacterial spot severity (19). Incorporation of fertilizers and organic products such as ALS into integrated disease management strategies not only provides a source of nutrients but also lowers environmental concerns of the public. Foliar sprays of fertilizers at a low application rate appear to be a practical alternative to copper. The use of fertilizers as foliar sprays to manage fungal foliar diseases of plant species has been described previously (3,14,25-27, 41).

Our study is the first one to test foliar fertilizer sprays as a means of managing bacterial diseases of tomato and bell pepper. This 3-year field study demonstrates that ALS, a nutrient-rich organic material, and KP reduce bacterial spot disease severity on tomato and pepper foliage and disease incidence on fruit. These treatments can be used in organic and conventional production systems without posing any threat of resistance development in the bacterial pathogens.

Acibenzolar- $S$-methyl (Actigard) is a plant activator and has been shown to induce systemic resistance in wheat and barley against fungal pathogens (13) and in tobacco against bacterial and fungal diseases (9). In this study, foliar applications of this compound significantly reduced bacterial spot severity on tomato and pepper foliage and disease incidence on fruit and increased the yield of healthy fruit. Though it has been used successfully in greenhouse and field experiments to control bacterial spot and speck on tomato and bacterial spot on pepper $(11,18,21,29)$, the use of acibenzolar- $S$-methyl is still experimental and not yet registered in Canada. The rates of this product effective against bacterial spot disease may be phytotoxic and can lead to yield reduction, particularly in pepper (29). Like acibenzolar-S-methyl, phosphate salts also are known as the inducers of SAR in plants $(14,27,41) . \mathrm{Cu}$ cumber leaves pretreated with potassium phosphate solution could not be penetrated by appressoria of the fungus Botrytis cinerea (3). Although our study was not aimed at examining the mechanisms responsible for the reduced bacterial disease severity on foliage and incidence on fruit, it is likely that KP and ALS may have increased the resistance potential of the plants to the bacterial spot and speck pathogens. We did not find any differences in the total number of epiphytic bacteria on tomato foliage treated with $\mathrm{KP}$, ALS, or acibenzolar-S-methyl from water-treated foliage (data not shown). Although the population data in this study is preliminary, it is likely that mechanisms other than direct toxicity to bacterial spot pathogen may have involved. In a previous study (18), acibenzolar- $S$ methyl had little or no effect on the populations of $X$. campestris pv. vesicatoria or $P$. syringae pv. tomato present on field tomato foliage. We also did not observe any differences in plant growth among the various treatments.

The fact that foliar applications of dilute solutions of an organic product such as ALS and of a common salt such as KP consistently reduced disease caused by such highly aggressive bacteria is rather remarkable and warrants further research. In the absence of any effective control measures against bacterial diseases of tomato and pepper, ALS and KP may be inexpensive alternative to producers. Further studies that examine optimal spray intervals, rates, adjuvants, and so on, however, are needed, preferably in commercial fields in order to determine what, if any, economic benefits may be realized from such treatments.

Table 4. Effect of weekly sprays of acibenzolar- $S$-methyl (Actigard), ammonium lignosulfonate (ALS), and potassium phosphate (KP) on the healthy and total yield of field tomato ${ }^{\mathrm{x}}$

\begin{tabular}{|c|c|c|c|c|c|c|}
\hline \multirow[b]{2}{*}{ Spray treatments } & \multicolumn{3}{|c|}{ Total healthy fruit $(\mathrm{t} / \mathrm{ha})^{\mathrm{y}}$} & \multicolumn{3}{|c|}{ Total yield (t/ha) } \\
\hline & 1999 & 2000 & 2001 & 1999 & 2000 & 2001 \\
\hline Control & $62 \mathrm{~b}$ & $19 \mathrm{~b}$ & $65 \mathrm{a}$ & $93 \mathrm{a}$ & $37 \mathrm{a}$ & $75 \mathrm{a}$ \\
\hline Actigard & $79 \mathrm{a}$ & $31 \mathrm{a}$ & $61 \mathrm{a}$ & $91 \mathrm{a}$ & $42 \mathrm{a}$ & $65 \mathrm{a}$ \\
\hline $\operatorname{ALS}(2 \%)$ & $65 \mathrm{~b}$ & $26 \mathrm{ab}$ & $62 \mathrm{a}$ & $90 \mathrm{a}$ & $45 \mathrm{a}$ & $68 \mathrm{a}$ \\
\hline $\operatorname{ALS}(4 \%)$ & $69 \mathrm{ab}$ & $30 \mathrm{ab}$ & $62 \mathrm{a}$ & 94 a & $48 \mathrm{a}$ & $69 \mathrm{a}$ \\
\hline $\mathrm{KP}$ & $70 \mathrm{ab}$ & $28 \mathrm{ab}$ & $60 \mathrm{a}$ & $89 a$ & $44 \mathrm{a}$ & $66 \mathrm{a}$ \\
\hline $\mathrm{ALS}+\mathrm{KP}^{\mathrm{z}}$ & $\ldots$ & $21 \mathrm{~b}$ & $61 \mathrm{a}$ & $\ldots$ & $39 a$ & $66 \mathrm{a}$ \\
\hline
\end{tabular}

${ }^{\mathrm{x}}$ Means followed by different letters within each column are significantly different $(P \leq 0.05$, least squares means option of the general linear models procedure of SAS).

${ }^{\mathrm{y}}$ Total healthy fruit, free of any disease symptoms.

${ }^{\mathrm{z}}$ A mixture of ALS (2\%) and KP (10 mM in 2000 and $25 \mathrm{mM}$ in 2001).

Table 5. Effect of weekly sprays of acibenzolar- $S$-methyl (Actigard), ammonium lignosulfonate (ALS), and potassium phosphate (KP) on the fruit number per plant and the healthy and total yield of field pepper $^{\mathrm{x}}$

\begin{tabular}{lcccccccc}
\hline & \multicolumn{2}{c}{ Fruit/plant } & & \multicolumn{2}{c}{ Healthy fruit $(\mathbf{t} / \mathbf{h a})^{\mathbf{y}}$} & & \multicolumn{2}{c}{ Total yield (t/ha) } \\
\cline { 2 - 3 } \cline { 8 - 9 } Spray treatments & $\mathbf{2 0 0 0}$ & $\mathbf{2 0 0 1}$ & & $\mathbf{2 0 0 0}$ & $\mathbf{2 0 0 1}$ & & $\mathbf{2 0 0 0}$ & $\mathbf{2 0 0 1}$ \\
\hline Control & $2.4 \mathrm{a}$ & $4.9 \mathrm{a}$ & & $0.1 \mathrm{a}$ & $6 \mathrm{~b}$ & & $5 \mathrm{a}$ & $16 \mathrm{a}$ \\
Actigard & $0.9 \mathrm{~b}$ & $3.9 \mathrm{a}$ & & $1.0 \mathrm{a}$ & $9 \mathrm{a}$ & & $2 \mathrm{~b}$ & $13 \mathrm{a}$ \\
ALS $(2 \%)$ & $2.5 \mathrm{a}$ & $6.4 \mathrm{a}$ & & $1.6 \mathrm{a}$ & $11 \mathrm{a}$ & & $7 \mathrm{a}$ & $20 \mathrm{a}$ \\
ALS $(4 \%)$ & $2.6 \mathrm{a}$ & $4.7 \mathrm{a}$ & & $0.8 \mathrm{a}$ & $9 \mathrm{a}$ & & $7 \mathrm{a}$ & $16 \mathrm{a}$ \\
KP & $2.3 \mathrm{a}$ & $4.3 \mathrm{a}$ & & $1.2 \mathrm{a}$ & $5 \mathrm{~b}$ & & $5 \mathrm{a}$ & $14 \mathrm{a}$ \\
ALS + KP & $2.4 \mathrm{a}$ & $5.5 \mathrm{a}$ & & $1.2 \mathrm{a}$ & $10 \mathrm{a}$ & & $7 \mathrm{a}$ & $17 \mathrm{a}$ \\
\hline
\end{tabular}

${ }^{\mathrm{x}}$ Means followed by different letters within each column are significantly different $(P \leq 0.05$, leastsquares means option of the general linear models procedure of SAS).

y Healthy fruit, free of any disease symptoms.

${ }^{\mathrm{z}}$ A mixture of ALS (2\%) and KP (10 mM in 2000 and $25 \mathrm{mM}$ in 2001). 


\section{ACKNOWLEDGMENTS}

We thank I. Lalin, B. Weselowski, R. Earl, R. Muth, and G. McFadden for technical assistance; and S. A. Miller (The Ohio State University), K. Conn (AAFC), and D. Vadnais (AAFC) for their critics and valuable suggestions during the preparation of the manuscript.

\section{LITERATURE CITED}

1. Abbasi, P. A., Al-Dahmani, J., Sahin, F., Hoitink, H. A. J., and Miller, S. A. 2002. Effect of compost amendments on disease severity and yield of tomatoes in conventional and organic production systems. Plant Dis. 86:156-161.

2. Adaskaveg, J. E., and Hine, R. B. 1985. Copper tolerance and zinc sensitivity of Mexican strains of Xanthomonas campestris pv. vesicatoria, causal agent of bacterial spot of pepper. Plant Dis. 69:993-996.

3. Akutsu, K., Takatsu, Y., Sakiyama, H., and Okuyama, S. 1987. Stimulative effect of potassium phosphate on infection of cucumber leaves by conidia of Botrytis cinerea. Ann. Phytopathol. Soc. Jpn. 53:175-181.

4. Alkanani, T., and MacKenzie, A. F. 1996. Banding urea and lignosulfonate in corn (Zea mays L.) production and ${ }^{15} \mathrm{~N}$ recovery. Can. J. Soil Sci. 76:365-371.

5. Buylov, V. V., Lichko, R. P., and Volokitin, M. P. 1979. Improvement of the properties of solonetzic soils with ammonium lignosulfonate. Sov. Soil Sci. 11:449-460 (English translation).

6. Callebaut, F., Gabriels, D., and Boodt, M. D. 1979. The effect of polymer structure on soil physio-chemical properties and soil water evaporation. J. Chem. Technol. Biotechnol. 29:723-729.

7. Campbell, C. L., and Madden, L. V. 1990. Introduction to Plant Disease Epidemiology. John Wiley \& Sons, Inc., New York.

8. Cihacek, L. J. 1984. Economic soil treatment of iron chlorosis in grain sorghum grown on a gypsum affected soil. J. Plant Nutr. 7:329340.

9. Cole, D. L. 1999. The efficacy of acibenzolar$S$-methyl, an inducer of systemic acquired resistance, against bacterial and fungal diseases of tobacco. Crop Prot. 18:267-273.

10. Cox, R. S. 1982. Control of bacterial spot of tomato in southern Florida. Plant Dis. 66:870.

11. Cuppels, D., Sahin, F., and Miller, S. A. 1999. Management of bacterial spot of tomato and pepper using a plant resistance activator in combination with microbial biocontrol agents. (Abstr.) Phytopathology 89:S19.

12. Cuppels, D. A., and Elmhirst, J. 1999. Disease development and changes in the natural Pseudomonas syringae pv. tomato populations on field tomato plants. Plant Dis. 83:759-764.

13. Görlach, J., Volrath, S., Knauf-Beiter, G., Henry, G., Beckhove, U., Kogel, K.-H., Oostendrop, M., Staub, T., Ward, E., Kessmann, H., and Ryals, J.1996. Benzothiadiazole, a novel class of inducers of systemic acquired resistance activates gene expression and disease resistance in wheat. Plant Cell. 8:629-643.

14. Gottstein, H. D., and Kuć, J. 1989. Induction of systemic resistance to anthracnose in cucumber by phosphates. Phytopathology 79:176-179.

15. Jones, L. B., Woltz, S. S., Jones, J. P., and Portier, K. L. 1991. Population dynamics of Xanthomonas campestris pv. vesicatoria on tomato leaflets treated with copper bactericides. Phytopathology 81:714-719.

16. Horsfall, J. G., and Barratt, R. W. 1945. An improved grading system for measuring plant diseases. (Abstr.) Phytopathology 35:655

17. Kousik, C. S., and Ritchie, D. F. 1996. Mixed genotypes combined with copper sprays to manage bacterial spot of bell peppers. Phytopathology 86:502-508.

18. Louws, F. J., Wilson, M., Campbell, H. L., Cuppels, D. A., Jones, J. B., Shoemaker, P. B., Sahin, F., and Miller, S. A. 2001. Field control of bacterial spot and bacterial speck of tomato using a plant activator. Plant Dis. 85:481-488.

19. McGuire, R. G., Jones, J. B., Stanley, C. D., and Csizinszky, A. A. 1991. Epiphytic populations of Xanthomonas campestris pv. vesicatoria and bacterial spot of tomato as influenced by nitrogen and potassium fertilization. Phytopathology 81:656-660.

20. Meier, J. N., Fyles, J. W., Mackenzie, A. F., and O'Halloran, I. P. 1993. Effects of lignosulfonate-fertilizer applications on soil respiration and nitrogen dynamics. Can. J. Soil Sci. 73:233-242.

21. Miller, S. A., Abbasi, P. A., Sahin, F., AlDahmani, J., and Hoitink, H. A. J. 1998. Control of foliar and fruit diseases of tomato by compost amendments and Actigard. (Abstr.) Phytopathology 88:S63.

22. Mohan, R., Ahmed, N. M. M., Thenammal, V., and Doraiswamy, S. 1978. Effect of potash on protein and various amino acid contents in chilli leaves infected with Xanthomonas vesicatoria (Doidge) Dowson. Curr. Sci. 47:776778.

23. Nayudu, M. V., and Walker, J. C. 1960. Bacterial spot of tomato as influenced by temperature and by age and nutrition of the host. Phytopathology 50:360-364.

24. Raese, J. T., Parish, C. L., and Staiff, D. C. 1986. Nutrition of apple and pear trees with foliar sprays, trunk injections of soil applications of iron compounds. J. Plant Nutr. 9:987999.

25. Reuveni, R., Dor, G., and Reuveni, M. 1998. Local and systemic control of powdery mildew (Leveillula taurica) on pepper plants by foliar spray of mono-potassium phosphate. Crop Prot. 17:703-709.

26. Reuveni, R., and Reuveni, M. 1998. Foliarfertilizer therapy-a concept in integrated pest management. Crop Prot. 17:111-118.

27. Reuveni, R., Reuveni, M., and Agapov, V. 1996. Foliar sprays of NPK fertilizers induce systemic protection against Puccinia sorghi and Exserohilum turcicum and growth response in maize. Eur. J. Plant Pathol. 102:339-348.

28. Ritchie, D. F., and Dittapongpitch, V. 1991. Copper- and streptomycin-resistant strains and host differentiated races of Xanthomonas campestris pv. vesicatoria in North Carolina. Plant Dis. 75:733-736.

29. Romero, A. M., Kousik, C. S., and Ritchie, D. F. 2001. Resistance to bacterial spot in bell peppers induced by acibenzolar-S-methyl. Plant Dis. 85:189-194.

30. Ryals, J., Uknes, S., and Ward, E. 1994. Systemic acquired resistance. Plant Physiol. 104:1109-1112.

31. Sahin, F., and Miller, S. A. 1995. Characterization of Ohio strains of Xanthomonas campestris pv. vesicatoria, causal agent of bacterial spot of pepper. Plant Dis. 80:773778.

32. Sajwan, K. S., and Lindsay, W. L. 1988. Response of flooded rice to various sources of zinc. J. Agric. Sci. 111:197-198.

33. Shaner, G., and Finney, R. E. 1977. The effect of nitrogen fertilization on the expression of slow-mildewing resistance in Knox wheat. Phytopathology 67:1051-1056.

34. Singh, J. P., Karamanos, R. E., Lewis, N. G., and Stewart, J. W. B. 1986. Effectiveness of zinc fertilizer sources on nutrition of beans. Can. J. Soil Sci. 66:183-187.

35. Soltani, N., Brown, A., Conn, K., and Lazarovits, G. 2000. Control of Verticillium wilt and potato scab with ammonium lignosulfonate. (Abstr.) Phytopathology 90:S73

36. Soltani, N., Conn, K., Abbasi, P. A., and Lazarovits, G. Reduction of potato scab and Verticillium wilt with ammonium lignosulfonate soil amendment in four Ontario potato fields. Can. J. Plant Pathol. In press.

37. Steel, R. G. D., Torrie, J. H., and Dickey, D A. 1997. Principles and Procedures of Statistics: A Biometrical Approach. 3rd ed McGraw-Hill Book Co., New York.

38. Sticher, L., Mauch-Mani, B., and Métraux , J. P. 1997. Systemic acquired resistance. Annu. Rev. Phytopathol. 35:235-270.

39. Vauterin, L., Hoste, B., Kersters, K., and Swings, J. 1995. Reclassification of Xanthomonas. Int. J. Syst. Bacteriol. 45:472-489.

40. Vidaver, A. K. 1967. Synthetic and complex media for the rapid detection of fluorescence of phytopathogenic pseudomonads: Effect of the carbon source. Appl. Microbiol. 15:15231524

41. Walters, D. R., and Murray, D. C. 1992 . Induction of systemic resistance to rust in Vicia faba by phosphate and EDTA: effect of calcium. Plant Pathol. 41:444-448.

42. Xie, R. J., Fyles, J. W., Mackenzie, A. F., and O'Halloran, I. P. 1991. Lignosulfonate effects on phosphate reactions in a clay soil: causal modeling. Soil Sci. Soc. Am. J. 55:711-716.

43. Xie, R. J., Mackenzie, A. F., and O'Halloran, I. P., and Fyles, J. W. 1994. Concurrent transformation of lignosulfonate carbon and urea nitrogen in clay soil. Soil Sci. Soc. Am. J. 58:824-828.

44. Xie, X. H., Mackenzie, A. F., Xie, R. J., Fyles, J. W., and O'Halloran, I. P. 1995. Effects of ammonium lignosulfonate and diammonium phosphate on soil organic carbon, soil phosphorous fractions and phosphorous uptake by corn. Can. J. Soil Sci. 75:233-238. 